\title{
IMPACT OF HRM PRACTICES ON TEACHERS' JOB PERFORMANCE IN PRIVATE SCHOOLS OF KARACHI
}

\author{
Faryal Sultan ${ }^{1}$, Charlotte Dominica Vincent ${ }^{2}$, and Fatima Aslam ${ }^{3}$ \\ ABSTRACT
}

Organizations must focus on their human resource as it is essential for organizational productivity. It is the primary responsibility on human resources management to employ efficient staff, so as to provide a productive workforce to the organizations. This study is applied in Karachi, to analyze the impact of human resource management (HRM) practices on the job performances of schoolteachers. Although there are several studies associated with this topic because the few HRM practices, but this paper is unique because it involves the major HRM practices and relate these with educational institutes of mega city. Data has been collected through questionnaire from teachers of primary and secondary level which highlighted the insufficiency of HRM practices in educational institute of Karachi, therefore, it is legitimate to consider that this study as pervasive.

Keywords: Compensation, Performance Evaluation, Training and Development, Promotion and Employee Performance.

\section{INTRODUCTION}

According to Yousaf, Usman and Islam (2018) education is a key component for building up a nation and the performance of the teachers contribute a huge part to the educational system. Education plays an integral part in building a nation. Teachers are vital components of any educational establishment (Ricard \& Pelletier, 2016). Even in days of technological advancement, the need of teachers is still a prevailing factor (Arifin, 2015). In fact, successes of the schools depend entirely on how well the teachers perform (Wildman, 2015). Ahmed,

123 KASBIT, Karachi, Pakistan 
Vveinhardt, Ahmed and Heman (2016) further stated that optimal employee performance and efficiency has been a major issue in the private and non- private schools. Although training and development may play a significant role shaping effectiveness of organizations as well as employees in their job (Khan \& Abdullah, 2019).

\section{STATEMENT OF THE PROBLEM}

Thillmann, Bach, Wurster and Thiel (2015) highlighted that limited research has been conducted on staff development in schools. Thus, organizations must focus on their manpower especially, as this is the primary responsibility is on human resources management and this management must perform their duties and provide suitable substrates for talented and capable forces in the organization so they can fulfill their duties in a better way (Andersson, 2007). HRM practices vary across regions and organizations (Sattar, Ahmad \& Hassan, 2015) and therefore need to follow Hashim, et al. (2017) that there is need to examine more HR practices about teachers' performance which may cover all of HR practices in Karachi, Pakistan. The statement is actionable as in education sector performance of teacher's leads to organizational success and will also contribute to the educational standards of Pakistan. Thus, the purpose of this study is to investigate the role of HR in educational institute with emphasize on schooling sector of Karachi.

\section{THEORATICAL FRAMEWORK}

Recruitment criteria, work plan, compensation structure, staff training and reward attached with effective performance are some of the important HR practices (Sattar et al., 2015), although monitoring must be supplemented in order to optimize the level of performance (Waseem, Frooghi \& Afshan, 2013). Some of the researchers also argue that performance evaluation and compensation is physiological needs in developing areas which have a significant impact on individual performance. Although, due to collectivist culture teacher's performance may depend on promotion, performance and compensation practices (Shahzad \& Bashir, 2008). Therefore, motivation must be used as a mediator as the HR functions aids to psychological needs of teachers associated with developing sides of the world. Although as mentioned above the monitoring is also required in order to optimize the effect of these HR managers. Thus, monitoring is used as the moderator in this stud .monitoring is used as the moderator. 


\section{SIGNIFICANCE OF STUDY}

The findings of this study will benefit the individuals who are budding researchers and for students who are aiming at passing a course or semester. Furthermore, study is based on educational institutions which are raising its effectiveness as well as significance as this type of studies are rare from Pakistan. Hence, study will produce positive influence on a section of our society and therefore must be termed as pervasive. Moreover, this study may aid in performance of teachers and may leads to betterment of the entire society.

\section{LITERATURE REVIEW}

Ahmed et al. (2016) indicated that the faculty has a major role in any educational institution especially in the optimization of image, productivity, research output and overall ranking. Especially in Pakistan, where teachers are not considered the most critical part of societies \& therefore there is a lack of attention towards this aspect, especially in terms of appreciation and rewards which may foster teacher's ability, confidence and motivation. In fact, Wong and Wong (2010) indicated that several organizations across the world over, including the ministry of Education, have tried to optimize practices of recruitment and promotions that could enhance achievement of organizational goals (Chabu, 2014). Statement is potent as, when the employees are rewarded financially they will be motivated to perform better. Compensation is a process of providing monetary worth to employees for the work they performed. It can be used to hire skilled employee, reward the performance, and encourage company loyalty by dropping the employee turnover (Altarawmneh \& Al-Kilani, 2010).

On the other side training and development is linked with organizational activity with an aim of improving the individual performance and also the performance of groups. In fact enhanced teachers' productivity to a great extent and concluded that teachers have to be trained at regular intervals and retrained them so as to improve their productivity at workplace (Khan \& Abdullah, 2019). Last but not the least Wong and Wong (2010) indicated that in the educational environment promotion is an important matter. Therefore the employees look towards promotion as a rewarding tool by which the educators will increase their standard of work laid down by their heads. Shahzad et al. (2008) found a very weak correlation between Performance evaluation practices and perceived performance of the employee. They declared that unproductive evaluation practice could lead to poor performance. 
A strong teacher evaluation system is significant to improving teacher performance quality. It supplies the resources to identify and reward great teachers so we can learn from and reproduce their success. It also supports to identify those who need help so they can get the extra training they need to be effective. Evaluations should use objective data too fairly and reliably measure teacher performance against the standards set by the institutes (Sedlis, 2015). Therefore, process of performance management is linked with career performance standards, evaluation, and institutional goals in order to examine and evaluate employee career performance consequence (Babalola, Olusegun, \& Bruning, 2015). Although motivation highlights every one of the motives which ground a man to does something as well as the negative ones like apprehension alongside the more affirmative thought processes (Adair, 2009).

\section{RESEARCH HYPOTHESES}

H1A: There is a positive impact of compensation on job performance.

H2A: There is a positive impact of training and development on job performance.

H3A: There is a positive impact of promotion on job performance.

H4A: Motivation mediates the relationship of compensation on job performance.

H5A: Motivation mediates the relationship of performance evaluation on job performance.

H6A: Motivation mediates the relationship of training and development on job performance.

H7A: Motivation mediates the relationship of promotion on job performance.

\section{RESEARCH METHODOLOGY}

\section{Research Design}

The philosophy behind this study is epistemology and the stance is post-positivism as the study is trying to uncover ideas which will aid to knowledge building through quantitative approach (Saunders et al., 2009). The purpose of research is correlational and study setting was noncontrived as the study was conducted with the ease of respondents but the framework was developed through merging prior studies (Sekaran \& Bougie, 2016). The research strategy was survey and the time horizon was cross-sectional as this study was based on data collection through closed ended questionnaire which are analyzed once through SMART-PLS (Saunders et al., 2009).

\section{Sampling Design}


Hashim et al (2017) used the formula of Yamane (1967) to determine the sample size, a total of 136 questionnaires were distributed. Alami, (2015) determine the sample size which comprised of 120 teachers by random sampling. Whereas Khalil et al. (2017) adopted stratified proportionate sampling technique for the selection of participants according to the nature of population. Although this study is based on school of Karachi as Karachi is not only the economic hub but also the most developed city of Pakistan. Therefore the best practices of HR are perceived to be a part of schooling system of Karachi as otherwise these sort of researches are rare from the point of view of Pakistan. Hence seems to be a theory building approach and therefore the sample of the study compromises of one-hundred school teachers working in different private schools of Karachi. Although the aim of the study is to collect data from those private schools which are affiliated with Karachi Board for SSC Exams rather than O-Levels education. The type of sampling is quota sampling to select 250 individuals who have at least two to three years of relevant experience and must be aware of HR practices of the institution where they are employed.

\section{STATISTICAL TESTING AND ANALYSIS}

Table 1. Quality Criteria (Predictive Accuracy)

R Square

\begin{tabular}{|l|r|r|}
\hline & $\begin{array}{l}\text { R } \\
\text { Square }\end{array}$ & $\begin{array}{l}\text { R Square } \\
\text { Adjusted }\end{array}$ \\
\hline $\begin{array}{l}\text { EMPLOYEE } \\
\text { PERFORMANCE }\end{array}$ & 0.658 & 0.584 \\
\hline MOTIVATION & 0.635 & 0.597 \\
\hline
\end{tabular}

Table 2Construct Reliability and Convergent Validity

\begin{tabular}{|l|r|r|r|r|}
\hline & \multicolumn{1}{|c|}{$\begin{array}{l}\text { Cronbach's } \\
\text { Alpha }\end{array}$} & rho_A & $\begin{array}{l}\text { Average } \\
\text { Composite } \\
\text { Reliability }\end{array}$ & $\begin{array}{l}\text { Variance } \\
\text { Extracted } \\
\text { (AVE) }\end{array}$ \\
\hline $\begin{array}{l}\text { COMPENSATION } \\
\text { (Comp.) }\end{array}$ & 0.773 & 0.828 & 0.827 & 0.557 \\
\hline $\begin{array}{l}\text { EMPLOYEE } \\
\text { PERFORMANCE (EP) }\end{array}$ & 0.752 & 0.890 & 0.894 & 0.599 \\
\hline MONITORING (Mon.) & 0.718 & 0.817 & 0.864 & 0.678 \\
\hline MOTIVATION (Mot.) & 0.756 & 0.795 & 0.783 & 0.531 \\
\hline
\end{tabular}




\begin{tabular}{|l|r|r|r|r|} 
Moderating Effect 1 & 1.000 & 1.000 & 1.000 & 1.000 \\
\hline Moderating Effect 2 & 1.000 & 1.000 & 1.000 & 1.000 \\
\hline Moderating Effect 3 & 1.000 & 1.000 & 1.000 & 1.000 \\
\hline Moderating Effect 4 & 1.000 & 1.000 & 1.000 & 1.000 \\
\hline $\begin{array}{l}\text { PERFORMANCE } \\
\text { EVALUATION (Per. Eva.) }\end{array}$ & 0.840 & 0.925 & 0.947 & 0.536 \\
\hline PROMOTION (Prom.) & 0.733 & 0.761 & 0.798 & 0.542 \\
\hline $\begin{array}{l}\text { TRAINING AND } \\
\text { DEVELOPMENT (T\&D) }\end{array}$ & 0.798 & 0.806 & 0.881 & 0.713 \\
\hline
\end{tabular}

\section{Construct Reliability and Validity}

Table 3 Discriminant Validity

\begin{tabular}{|l|r|l|l|l|l|l|l|l|l|l|l|}
\hline & Comp. & EP & Mon. & Mot. & ME 1 & ME 2 & ME 3 & ME 4 & Per Eva & Prom. & T\&D \\
\hline Comp. & & & & & & & & & & & \\
\hline EP & 0.534 & & & & & & & & & & \\
\hline Mon. & 0.485 & 0.730 & & & & & & & & & \\
\hline Mot. & 0.349 & 0.712 & 0.731 & & & & & & & & \\
\hline ME 1 & 0.120 & 0.322 & 0.307 & 0.271 & & & & & & & \\
\hline ME 2 & 0.184 & 0.390 & 0.259 & 0.197 & 0.264 & & & & & & \\
\hline ME 3 & 0.184 & 0.475 & 0.230 & 0.099 & 0.180 & 0.279 & & & & & \\
\hline ME 4 & 0.106 & 0.434 & 0.310 & 0.037 & 0.070 & 0.626 & 0.100 & & & & \\
\hline Per. Eva. & 0.702 & 0.314 & 0.639 & 0.707 & 0.203 & 0.561 & 0.211 & 0.223 & & & \\
\hline Prom. & 0.312 & 0.659 & 0.756 & 0.690 & 0.164 & 0.123 & 0.251 & 0.168 & 0.709 & & \\
\hline T\&D & 0.138 & 0.747 & 0.429 & 0.637 & 0.119 & 0.054 & 0.098 & 0.100 & 0.686 & 0.624 & \\
\hline
\end{tabular}

Heterotrait-Monotrait Ratio (HTMT)

Table 4 Path-Coefficient (Total Effects)

\begin{tabular}{|l|r|r|r|r|r|}
\hline & $\begin{array}{c}\text { Original } \\
\text { Sample } \\
(\mathbf{O})\end{array}$ & $\begin{array}{c}\text { Sample } \\
\text { Mean } \\
(\mathbf{M})\end{array}$ & $\begin{array}{c}\text { Standard } \\
\text { Deviation } \\
(\mathbf{S T D E V})\end{array}$ & $\begin{array}{l}\text { T Statistics } \\
(|\mathbf{O} / \mathbf{S T D E V}|)\end{array}$ & P Values \\
\hline Comp -> EP & 0.080 & 0.048 & 0.185 & 4.333 & 0.046 \\
\hline Comp -> Mot & -0.151 & -0.177 & 0.196 & 7.769 & 0.044 \\
\hline Mon -> EP & 0.268 & 0.252 & 0.171 & 6.571 & 0.012 \\
\hline Mot-> EP & 0.221 & 0.135 & 0.235 & 4.939 & 0.035 \\
\hline ME 1 -> EP & -0.096 & -0.036 & 0.139 & 2.694 & 0.049 \\
\hline ME 2 -> EP & 0.122 & 0.057 & 0.192 & 9.635 & 0.043 \\
\hline ME 3 -> EP & -0.089 & -0.029 & 0.133 & 3.667 & 0.031 \\
\hline ME 4 -> EP & 0.074 & 0.046 & 0.159 & 2.465 & 0.046 \\
\hline Per Eva -> Mot & 0.186 & 0.239 & 0.220 & 8.845 & 0.040 \\
\hline Prom. -> Emp Per & 0.196 & 0.210 & 0.242 & 7.810 & 0.042 \\
\hline Prom. -> Mot. & 0.103 & 0.055 & 0.239 & 22.432 & 0.027 \\
\hline T\&D -> Emp. Per. & -0.011 & 0.065 & 0.145 & 10.075 & 0.049 \\
\hline
\end{tabular}




\begin{tabular}{|l|r|r|r|r|r|}
\hline T\&D -> Mot. & 0.182 & 0.152 & 0.167 & 3.089 & 0.028 \\
\hline \multicolumn{3}{c}{ Mean, STDEV, T-Values, P-Values }
\end{tabular}

Table 4 indicated that $\mathrm{t}$-values for all the cases are higher than 1.97 and $\mathrm{p}$-values are lesser than 0.05. Therefore it is legitimate to believe that teachers working in educational sector of Karachi perceive each and every variable as the predictor of teacher's motivation which ultimately resulted in their performance.

These parameters associated with inferential statistics through SMART-PLS are consistent with Hair et al. (2011) and Kock and Hadaya (2018). Therefore, this must be termed potent in measuring the reflective model according to the indication of Andreev et al (2014).

\section{CONCLUSION AND DISCUSSION}

Results of the study indicated that findings are seems to be consistent with Chabu (2014) and Altarawmneh and Al-Kilani (2010) as methods of recruitment as well as procedure of intake of employees has significant impact on their performance. Similarly, study is also consistent with Khan and Abdullah (2019) and Wong and Wong (2010), as training and development as well as promotion capacities of school are also significant in this regards. Last but not the least study also proves the inclusion of mediation as moderation in the study, as it is also consistent with the postulates of Shahzad and Bashir (2008) and Waseem et al. (2013)

\section{AREA FOR FUTURE RESEARCH}

This study has been conducted on those private schools which are associated with SSC education and therefore one of the pervasive studies might be conducted to explore the change of perception in teacher working in private and government sector schools. Moreover, study might also check the same at provincial level or in other major cities like Lahore, Islamabad and Quetta etc. 


\section{REFERENCES}

Abbas, Z. (2014). Identification of factors and their impact on employees' training and organizational performance in Pakistan. Kasbit Journal of Management \& Social Science, 7(1), 93-109.

Ahmad, S., \& Shahzad, K. (2011). HRM and employee performance: A case of university teachers of Azad Jammu and Kashmir (AJK) in Pakistan. African journal of business management, 5(13), 5249.

Ahmed, R. R., Vveinhardt, J., Ahmed, M. \& Hemani, K.R. (2016). Determinants of Faculty Performance of Business Schools: Empirical Evidence from Pakistan. 8th annual International Conference on Education and New Learning Technologies (EDULEARN2016), pp. 4219-4228, ISBN: 978-84-608-8860-4, At Barcelona, Spain

Akhtar, J. H. \& Iqbal, E. (2017). Impact of Motivation on Teachers' Job Performance: A Case Study of a Public Sector University. Journal of educational Sciences \& Research, Vol. $4(1)$.

Altarawmneh, I., \& Al-Kilani, M. H. (2010). Human resource management and turnover intentions in the Jordanian hotel sector. Research and Practice in Human Resource Management, 18(1), 46-59.

Andersson, C. (2007), “Teacher density and student achievement in Swedish compulsory schools", Working Paper 2007:4, Institute for Labour Market Policy Evaluation (IFAU), Uppsala

Andreev, P., Heart, T., Maoz, H., \& Pliskin, N. (2009). Validating formative partial least squares (PLS) models: methodological review and empirical illustration. ICIS 2009 proceedings, 193

Arifin, H. M. (2015). The Influence of Competence, Motivation, and Organisational Culture to High School Teacher Job Satisfaction and Performance. International Education Studies, 8(1), 38-45. 
Barclay, D., Higgins, C., \& Thompson, R. (1995). The partial least squares (PLS) approach to casual modeling: personal computer adoption and use as an Illustration. Technology studies 2: 285-309

Bichi, A. A. (2017). Evaluation of Teacher Performance in Schools: Implication of Sustainable Development Goals. Northwest Journal of Educational Studies, Vol. 2(1).

Chabu, G. (2014). Recruitment and Promotion Practices in the Police Service. MA MPA Dissertation. The University of Zambia.

Chin, W. W. (1998). The partial least squares approach to structural equation modeling. Modern methods for business research, 295(2), 295-336

Dessler, G. (2008). Human Resource Management (1 $1^{\text {th }}$ edition), New Delhi, Prentice Hall, of India Private Ltd.

Fornell, C., \& Larcker, D. F. (1981). Evaluating structural equation models with unobservable variables and measurement error. Journal of marketing research, 18(1), 39-50

Geofrey, Y. (2010). Motivation and Academic Staff Performance In Public Universities In Uganda: The Case Of Makerere University. Retrieved from http://dspace.mak.ac.ug/handle/1234 56789/1339.

Guest, D. (2002). Human resource management, corporate performance, and employee wellbeing: building the worker into HRM. The Journal of Industrial Relations, 44(3): 335358.

Hair, J. F., Ringle, C. M., \& Sarstedt, M. (2011). PLS-SEM: Indeed, a silver bullet. Journal of Marketing theory and Practice, 19(2), 139-152

Hair, J. F., Ringle, C. M., \& Sarstedt, M. (2013). Partial least squares structural equation modeling: Rigorous applications, better results and higher acceptance. Long range planning, 46(1-2), 1-12 
Hair, J. F., Sarstedt, M., Ringle, C. M., \& Mena, J. A. (2012). An assessment of the use of partial least squares structural equation modeling in marketing research. Journal of the academy of marketing science, 40(3), 414-433.

Hair, J.F., Ringle, C.M., \& Sarstedt, M. (2011). PLS-SEM: Indeed, a silver bullet. The Journal of Marketing Theory and Practice, 19(2), 139-152

Hashim, M., Rafi, S., Kazmi, S.S.A., Ullah, M. and Dr. Kee, D.M. H. (2017).Impact of Human Resource Practices On Perceived Performance: a study of teaching faculty in private universities of Peshawar, Pakistan, City University Research Journal, Special Issue: AIC, pp 120-129

Hassan S. (2016). Impact of HRM practices on Employee's Performance. International Journal of Academic Research in Accounting, Finance and Management Sciences, 6(1), 15-22.

Heaton, T.L., (2016). Handbook of instructional Leadership. Retrieved from $\underline{\text { http://digitalcommons.cedarville.edu/education_presentations/280 }}$

Henseler, J., Ringle, C. M., \& Sinkovics, R. R. (2009). The use of partial least squares path modeling in international marketing. In New challenges to international marketing (pp. 277-319). Emerald Group Publishing Limited

Hussain, S., Fangwei, Z., Siddiqi, A., Ali, Z., \& Shabbir, M. (2018). Structural equation model for evaluating factors affecting quality of social infrastructure projects. Sustainability, 10(5), 1415

Khan, S. \& Adullah N.N (2019). The impact of staff training and development on teacher's productivity. Economics, Management and Sustainability,4(1), 37-45. DOI: https://doi.org/10.14254/jems.2019.4-1.4 
Khan, S., \& Abdullah, N. N. (2019). The impact of staff training and development on teachers' productivity. Economics, Management and Sustainability, 4(1), 37-45. doi:10.14254/jems.2019.4-1.4.

Kock, N., \& Hadaya, P. (2018). Minimum sample size estimation in PLS-SEM: The inverse square root and gamma-exponential methods. Information Systems Journal, 28(1), $227-261$

Masum, A.K.M., Azad, M.A.K., \& Beh, L-S. (2015). Determinants of Academics' Job related to teacher performance management (doctoral dissertation). Walden

Ricard N. C. \& Pelletier L. G. (2016). Dropping out of high school: the role of parent and teacher self- determination support, reciprocal friendships and academic motivation. Contemporary Educational Psychology, 44-45, 32-40.

Sattar, T., Ahmad, K., \& Hassan, S. M. (2015). Role of human resource practices in employee performance and job satisfaction with mediating effect of employee engagement. Pakistan Economic and Social Review, 81-96

Saunders, M., Lewis, P., \& Thornhill, A. (2009). Research methods for business students. Pearson education

Sawchuk, S. (2015). Issues A-Z: Teacher evaluation: An issue overview. Education Week. $\begin{array}{llll}\text { Retrieved } & \text { April, } & 24, & 2017\end{array}$ http://www.edweek.org/ew/section/multimedia/teacher-performanceevaluation-issueoverview.html/

Sedlis, J. (2015). The Importance of Teacher Evaluations. City \& State New York. cityandstateny.com/articles/policy/education/the-importance-of-teacherevaluations.html

Sekaran, U., \& Bougie, R. (2016). Research methods for business: A skill building approach. John Wiley \& Sons. 
Shahzad, K., Bashir. S., \&Ramay, M.I. (2008). Impact of HR practices on the perceived performance of university teachers in Pakistan, Int. Rev. Bus. Res. Papers, 4(2). 302315.

Siringi. S. (2012). Secondary School Heads Refuse to Sign Performance Contracts. Daily nation February 10th 2012. Nairobi: Nation media group.

Sohaei, R. A. R, Younesi, A. K. M. B. A., Farnia, M. \&Mirzajani, H. (2015). The Effectiveness of Human Resource Management on Improving the Performance of Education Staff. Journal of Business and Social Science, 6(5)

Tumilaar, B. R. (2015). The effect of discipline, leadership, and motivation on employee performance at bpjsketenagakerjaansulut. Jurnalrisetekonomi, manajemen, bisnisdanakuntansi, 3 (2)

Waseem S. N., Farooghi, R. \&Afshan S. (2013). Impact of Human Resource Management Practices on Teachers' Performance: A Mediating Role of Monitoring Practices. Journal of Education and Social Sciences, 1(2) 31-35.

Wati, H. (2011). The effectiveness of Indonesian English teachers training programs in improving confidence and motivation. Online Submission, 4 (1), 79-104.

Wildman, R. H. (2015). A phenomenological study of high school teachers' motivation as Satisfaction: Empirical Evidence from Private Universities in Bangladesh. PLoS ONE, 10, 2,e0117834. doi: 10.1371/journal.pone.0117834

Wong, P. M. and Wong, C. S (2010). Promotion Criterion and Job Satisfaction of School Teachers in Hong Kong. Educational Management Journal, 33(4), 42-447.

Yousaf S. U., Usman B. \& Islam, T. (2018). Effects of Supervision Practices of Principals on Work Performance and Growth of Primary School Teachers. Bulletin of Education and Research, 40 (1) 285-298.

Zachary, W., Eleazar, V., \& Wilfred, W. (2016). The Impact of Simulated Interviews for Individuals with Intellectual Disability. Journal of Educational Technology \& Society, 19(1), 76-88. 